\title{
Digital Marketing: A Conceptual Framework, Review, and Case Study Mixed Approach
}

Submitted 14/10/19, 1st revision 16/03/20, 2nd revision 28/04/20, accepted 30/07/20

\section{Ramiro Esqueda-Walle ${ }^{1}$, Jesús Marmolejo Rodríguez ${ }^{2}$, Karla Villarreal Estrada ${ }^{3}$}

\begin{abstract}
:
Purpose: To analyze marketing and digital marketing activities implemented by three companies of Rio Bravo (Tamaulipas, Mexico) that are leaders in their industries. Being companies that over time have reached a solid position in the local market and the last five years have extended their market influence in the cross-border region of northern Tamaulipas and Lower Rio Grande Valley.

Approach/Methodology/Design: The study is exploratory with an explanatory scope, implemented a mixed-methodological approach, and developed an analytical framework based on triangulation precepts. As research techniques, we conducted a questionnaire (validated by experts), semi-structured interviews, and a web quality analysis tool to examine more than fifty search engine optimization parameters.

Findings: Marketing is conceived and applied in a segmented way, often as just advertising, and seen as something to improvise and thus reducing its potential benefits in market expansion. However, investing and implementing digital marketing tools benefits business expansion and market growth. To optimize results is urgent training managers in digital marketing, mainly in handling social networks and implement continuous performance assessment using web analytics tools.

Practical Implications: From the results, the paper draws up a set of recommendations to each company analyzed that may help to improve decision-making in marketing practices. The study also contributes to filling the gap in the scientific literature.

Originality/Value: This research is novel because of its mixed methodological approach based on different techniques that together offer an analysis based on the criterion of analytical and casuistic triangulation. Beyond the traditional focus on marketing, this work approaches cross-border marketing with an emphasis on the digital aspect. The selection case provides additional value because there is no previous study at this level.
\end{abstract}

Keywords: Cross-border companies, digital marketing, qualitative research, social networks.

JEL classification: M16, M31, M39.

Paper Type: Research article.

\footnotetext{
${ }^{1}$ Corresponding author, Autonomous University of Tamaulipas (México), resquedaw@uat.edu.mx

${ }^{2}$ Autonomous University of Tamaulipas (México), jmarmolejo@uat.edu.mx

${ }^{3}$ Autonomous University of Tamaulipas (México), karla.villarreal@uat.edu.mx
} 


\section{Introduction}

Certainly, globalization has had its main manifestation in the integration of international markets, which continues to deepen, however, for the most Mexican companies it remains a pending issue, even for those located in the northern border regions despite their strong and historical functional cross-border relationship with their U.S. counterparts. In this context, the application of international expansion strategies through different modalities is both necessary and a consequence for companies that manage to consolidate their operations in local-regional markets. Thus, offering their products and services at an international level enables them to expand to new markets, which they will only be able to exploit and maintain based on the competitiveness they develop, and for this purpose marketing strategies are essential.

While there are benefits to entering international markets, in practice the successful expansion of companies without previous experience is a very serious challenge and implies risks, even for those organizations that only intend to "cross the border", that is, operate in cross-border contexts of which in various ways they are already part, as is the case with the cities and metropolitan areas of the north of Mexico and the south of United States. Regarding some of the factors that influence international expansion decisions, Daniels et al. (2018), point out that the company's previous experience, as well as the degree of desire they have over the level of operational control in the foreign market, are some of the main determinants of success.

Due to the increasing competition, companies react in various ways, depending on their resources, positioning, environment, and market characteristics. In this sense, those that are in a dominant market position at the local level seek to consolidate themselves and to do so a key strategy is to extend their reach beyond their borders of origin, which is usually the immediate step towards the region of influence. Beyond the traditional focus on marketing, this work approaches cross-border marketing with an emphasis on the digital aspect, to refer to the actions that in this matter are implemented by companies that operate in regional cross-border markets such as those of northern Mexico and the southern United States. At this spatial scale, marketing is of high strategic value, since these territories have been characterized by being very dynamic in economic and commercial terms, and the flow of services, goods, and people are very high.

We consider this research interesting for its managerial implications as well as from a regional perspective since it can contribute to strategic decision-making. The contribution in the field of academic studies is also relevant because we analyzed the conception and practice of digital marketing implemented by three companies from Río Bravo, Tamaulipas (northeast Mexico) that are leaders in their industry, with more than 15 years of operations and have extended their market share to the crossborder region of northern Tamaulipas and the Lower Rio Grande Valley (southeast of Texas, United States). The selection case provides additional value because there 
is no previous study at the local level, and at the regional level, only two from a different approach and scope (Vargas, 2005; Oliveras, 2015).

The research objectives of this study are: i) to analyze the role that marketing plays in the selected companies; ii) to know how digital marketing practices are managed; iii) to determine its degree of application and knowledge at a management level; iv) to identify its results and to draw up a set of recommendations that may improve decision-making. As a hypothesis, we propose that marketing is an activity that, even though it is considered a priority, is poorly conceived and implemented in a limited way.

In addition to the topic, this research is novel because of its mixed methodological approach based on different techniques that together offer an analysis based on the criterion of analytical and casuistic triangulation. Data triangulation combines data extracted either from different sources, different times, different places, or different people (Flick, 2004; 2018). Several qualitative research techniques were implemented, mainly the semi-structured interview and the questionnaire validated by experts - through the focus group technique - to managers of marketing areas and web quality analysis tools based on the Metricspot software used, which enables the analysis of more than fifty SEO (Search Engine Optimization) parameters. The information from the fieldwork was generated between August 2017 and July 2019.

\section{Literature Review}

Digital marketing has evolved from a specific term describing the marketing of products and services using digital channels to a general term describing the process of using digital technologies to acquire customers and establish their preferences, promote brands, retain customers and increase sales. Following the American Marketing Association's approach, it is the use of digital or social channels to promote a brand or reach consumers. This type of marketing can be implemented within social media, search engines, the Internet, mobile devices, and other channels. It involves activities, institutions, and processes facilitated by digital technologies to create, communicate, and deliver value to customers and other stakeholders. In this research we take a more inclusive perspective as proposed by Kannan and Li (2017), understanding it as a flexible, technology-based process by which companies cooperate with stakeholders to jointly generate, communicate, provide and retain added value for all agents.

In this way, the second generation of Internet-based applications improves marketing efforts enabling companies to implement innovative forms of communication and "co-create" content with their customers. Based on an empirical study focused on marketing managers, Tiago and Veríssimo (2014), mention that companies have internal and external pressures to be on social media networks. Social networks are transforming consumer participation and engagement, people identify the use of social media networks as one of the elements that change the way companies 
compete in the globalized world. Thus, its analysis can be a tool for generating relevant information (Gálvez and Martín, 2009; Liang and Turban, 2011). These changes have impacted management and marketing practices worldwide, however, due to frequent use within social networks, Facebook stands out as the main one.

Based on the data generated by the software Statista (2020) for the analysis of statistics on the impact of social networks, Facebook remains at the top with a total of 2,449 million users followed by YouTube with 2,000 million and WhatsApp with 1,600 million. Twitter is below Instagram and Facebook's Messenger with only 340 million active people on this network. In the case of Mexico, Facebook remains the preferred social network with $95 \%$ of preferences, followed by WhatsApp with $93 \%$, YouTube with $72 \%$, and Twitter with $66 \%$. On average Mexican users have five social networks (Martinez, 2017). The professional social network LinkedIn is used by $56 \%$ of Internet users, an important fact is this social network focus in business, this means that about half of Mexican Internet users show interest in a business profile $^{4}$.

Due to its usefulness and impact, the application of Facebook as a business marketing tool has been studied for multiple cases, including those applied to SMEs in Argentina, Australia, the United States, China, Ghana, Italy, Jordan, Malaysia, Pakistan, Poland, and Mexico (Cañueto, 2016; McDaniel and Parks, 2019; Banks and Haan, 2017; Chang et al., 2017; Dzisi and Ofosu, 2014; Galati et al., 2017; Ganideh and Hamam, 2019; Ainin et al., 2015; Ayswarya et al., 2019; Chmielecki, 2014; Gutiérrez-Leefmans et al., 2016). Despite the diversity of approaches and study environments, there are coincidences in the findings, among them that this digital platform is chosen mainly for its low cost, simplicity of use, visibility, and impact on improving business performance. However, it is important to mention this tool has not been used to its full potential due to the lack of digital skills and management commitment.

At this point, it is worth highlighting the results of the Future of Business Survey ${ }^{5}$-a joint initiative of Facebook, the Organization for Economic Cooperation and Development (OECD) and the World Bank- as it is the largest on the subject so far, in terms of sample and country coverage, as it analyzes data from 336,000 SMEs in 42 countries for the period 2017-2018. In general, the results reveal the benefit from international trade is greater in companies that rely on the aforementioned digital platform, but with varying results, for example, the proportion of companies on the digital platform that engages in foreign trade ranges from 8 percent (Argentina) to 31 percent (Bangladesh). Analyzing the case of Mexico, we found that 14.9 percent of

\footnotetext{
${ }^{4}$ According to the latest AMIPCI data from 2019, these trends continue, however, the highest frequency of Internet use by Mexicans is $82 \%$ to social networks.

${ }^{5}$ Vid. Facebook, the Organization for Economic Cooperation and Development, and the World Bank, Future of Business Survey (dataset), accessed October 2019, https://eu.futureofbusinesssurvey.org/
} 
the companies that use Facebook participated in international trade, which reveals a propensity greater than SMEs in general (10 percent), according to figures for 2017 by ENAPROCE-INEGI ${ }^{6}$, nearly 4.2 million establishments, just 4.6 percent participate in such activities.

While the above studies mentioned the implications of digital marketing from various approaches, they all do so from a traditional conception of international marketing. In other words, they conceive the national space as an integrated whole and ignore regional particularities, especially those that occur in border areas. On this point, more than two decades ago, Clark (1994) raised the need for a theoretical and conceptual model to analyze the influence of territorial boundaries on agents in their immediate neighborhood, the border zone. This because the dynamics of national systems reach national boundaries resulting in discontinuities produce spatial complexities that are critically important for marketing behavior in those areas.

Previous work in this thematic line is still scarce, among which we highlight the following. Nijssen and Herk (2009), based on the empirical evidence provided by a case study focusing on the German-Dutch border, refer to the need to extend research on international marketing, since the influence of international marketing constructs on the growing cross-border trade relationship with service providers have been ignored.

On the other hand, Epetimehin (2013), focuses on the case of the Nigerian border, analyzing decision-making in the process of cross-border marketing planning and the competencies that can be developed to respond creatively to the changing global environment in light of the challenges of cross-border marketing. Based on a random sample of 156 senior executives from insurance companies with cross-border activities Grounded theory was used to summarize answers to some of the questions posed to some of the CEOs and heads of insurance companies involved in crossborder marketing. The qualitative data collected were analyzed through content analysis. He concludes that quality will be the ultimate criterion in cross-border competition, and quality will be determined by professional competence. Therefore, leadership development implies paradigm shifts.

Meanwhile, Teemu (2016) analyses the economic impact of cross-border marketing in southern Jutland (in Denmark just north of the German border). Empirical evidence suggests that the positive effect of cross-border shopping in attracting large numbers of tourists to the region can offset the negative effect of tourists preferring border shops to local products and services. Cross-border shopping has become itself a tourist attraction, benefiting local economies on both sides of the border. However, this potential is not recognized in the marketing of tourist destinations. Therefore, the article concludes with suggestions for the tourism industry to develop the image

${ }^{6}$ Cfr. https://www.inegi.org.mx/programas/enaproce/2018/ 
and brand by integrating cross-border shopping into the marketing strategies of tourist destinations.

Despite the great potential for studies in this field, for the Mexican case, no studies on digital marketing practices in cross-border companies were identified until the end of 2019. However, some references mention the topic from the traditional perspective ( $c f r$. Vargas, 2005; Oliveras, 2015). Therefore, we propose for the research agenda to adopt as a conceptual and instrumental framework the study of transnational regions with a close functional relationship - economic, social, political and territorial - as cross-border marketing, to refer to the actions implemented by companies operating in the markets of cross-border regions such as those of northern Mexico and the southern United States. In fact, at this spatial scale, marketing is a key strategic value, because these territories are known by being very dynamic in economic and commercial terms with a very high flow of services, goods, and people. International marketing strategies are undoubtedly also very relevant in these contexts, as they are for areas with a macro or transnational scope.

\section{Regional and Business Context}

The companies studied have their origin and continue to be established in the municipality of Río Bravo (RB) (Tamaulipas, Mexico), which is part of a crossborder macro region between Mexico and the United States of America. This area in the last three decades has registered population and economic growth rates above the national averages of the respective countries. However, companies have extended some of their market influence on the cross-border sub-region known as the Lower Rio Grande Valley (LRGV) (South east of Texas, United States) (Figure 1).

Figure 1. Location of Río Bravo and its regional cross-border area of influence

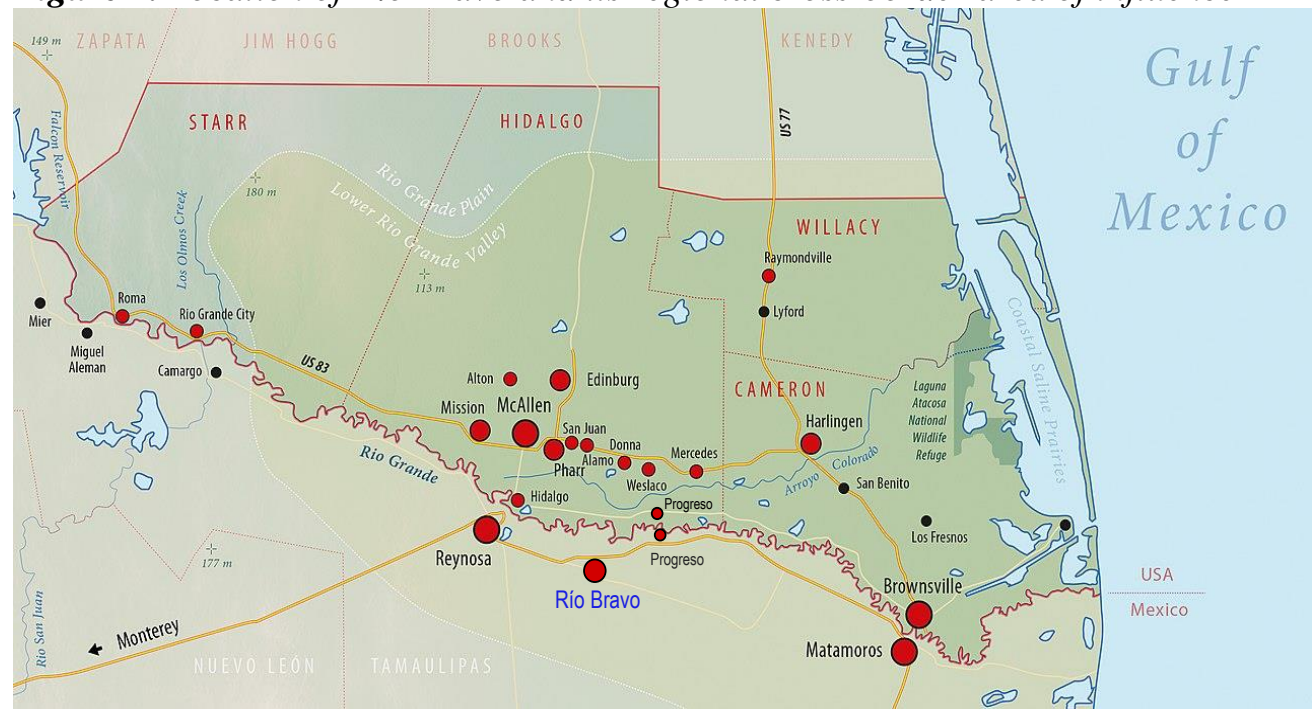

Source: Adapted from Rio Grande Valley Chamber of Commerce. 
According to official estimates (CONAPO, 2018), the municipality of Río Bravo will have a population of 136,000 in 2020 . The main economic activities correspond to the commercial and services sector with $68 \%$ of the personnel employed and have a low unemployment rate, which has averaged $4.2 \%$ over the last decade. ${ }^{7}$ The economic and social dynamics, like other cross-border regions in Mexico, are influenced by the growing flow of trade and people through its two land crossings ${ }^{8}$ with the United States, totaling 1,034,129 pedestrian crossings, 1,275,057 private vehicle crossings and 50,795 commercial truck crossings by $2018^{9}$. As for the three companies under study, it should be noted that they were selected because of their market leadership and according to the criteria established in the methodology section. Since no data is available on regional market performance or information to identify market positioning, we made an indirect estimate considering the number of employees as a proxy. To do so, we compare the data provided by the company with the total number of personnel employed in their respective industry with data from the last three Economic Censuses (2014-2019) (Table 1).

Table 1. Share of employed personnel and establishments (2004-2019)

\begin{tabular}{|l|l|l|l|l|l|l|}
\hline \multirow{2}{*}{ Company } & $\begin{array}{l}\text { NAICS* code and name } \\
\text { of industry }\end{array}$ & \multicolumn{2}{|l|}{$\begin{array}{l}\text { Establishments in the } \\
\text { municipality }\end{array}$} & $\begin{array}{l}\text { Total } \\
\text { municipal } \\
\text { personnel } \\
\text { employed }\end{array}$ & $\begin{array}{l}\text { Companies' } \\
\text { employment } \\
\text { share, 2019 (\%) }\end{array}$ \\
\cline { 3 - 7 } & $\mathbf{2 0 0 9}$ & $\mathbf{2 0 1 4}$ & $\mathbf{2 0 1 9}$ & 635 & $9 \%$ \\
\hline "B" & 81211 (Beauty Salons) & 191 & 217 & 261 & 635 & $51 \%$ \\
\hline "C" & $\begin{array}{l}484 \text { (Truck } \\
\text { transportation) }\end{array}$ & 6 & 8 & 9 & 711 & $41 \%$ \\
\hline
\end{tabular}

Note: * North American Industry Classification System, version 2018.

Source: Own elaboration based on INEGI Economic Censuses (2009, 2014, 2019).

Table 1 shows the classification of the industry in which each company participates according to the North American System of Industrial Accounts (NAICS). Through the analytical summary of the number of establishments, personnel employed and the share of employees, their relevance in the regional context is evident. The company's share of employees in its respective sector is noteworthy.

Although the tendency in the number of companies is increasing, most of the market is still held by the leaders. It is likely that given the "saturation" of the local market and to continue preserving their advantage, they have undertaken the strategy of strengthening growth in the cross-border market. The main characteristics of the companies and their activities are as follows:

\footnotetext{
${ }^{7}$ According to own estimates based on ENOE-INEGI. It should be noted that, as in the rest of the country, informality in employment is high, as it amounts to approximately $40 \%$.

${ }^{8}$ Río Bravo-Donna International Bridge and Nuevo Progreso-Progreso International Bridge.

${ }^{9}$ According to figures from Texas Department of Transportation (2019).
} 


\section{Company " $A$ "}

It was founded in 1995 and is still managed by its owner and founder. It has 57 employees of whom 5 are cashiers, 6 are cleaning and maintenance staff, and the remaining 45 are operational staff working on a commission basis. The services offered are manicure, pedicure, waxing, and acrylic nails. Their policies and business criteria are punctuality, well groomed, wear the uniform, and offering the best service. The physical facilities consist of a two-story building with approximately 450 square meters of construction that includes spaces such as a waiting room and dining room, it also has parking spaces for 50 vehicles.

\section{Company " $B$ "}

Also founded in 1995, managed by a board of directors. Dedicated to transport of commercial cargo and because of the frequency and scope of its operations has branches in several cities in Mexico (Monterrey, Nuevo Laredo, Manzanillo, and Mexico City) also in the United States (Pharr and Laredo). It has a total of 361 employees including managers, national operators, cross-border operators, and field staff. It has an inventory of 400 late-model transport vehicles and 1000 semi-trailers.

\section{Company " $C$ "}

Although at the beginning only marketed agricultural inputs, currently is one of the largest agricultural financing and marketing companies, for this reason, operate "Contract Farming" schemes. Has 17 years of experience, employs 38 people and has a register of more than 300 business partners who are farmers in the region, to sum up, an area of more than 12,000 hectares suitable for the growing of sorghum and corn. The following facilities stand out: a large warehouse for the reception and shipment of the supplies it sells self-service station for the supply of fuel and lubricants; two large warehouses strategically located, with access to a railroad spur, for the reception, handling, and shipment of grains with a capacity of 60,000 tons; branch office in the neighboring city of Weslaco, Texas. While the companies are in the tertiary sector, their activities are completely different. Their relative preponderance reveals coincidences in leadership and in the high amounts of investment they have made in infrastructure to have enough service capacity. Based on the number of employees, companies" " $\mathrm{A}$ " and "C" are classified as medium, and "B" as large.

\section{Methodology}

The methodological process is based on the criteria of the triangulation approach. Consists of a combination of different sources and methods which ensure analytical validity and reliability. This way, the knowledge gained is more reliable from a variety of approaches. Due to the constraints of secondary information, the characteristics of the study environment, and the caution of research subjects to provide information explicitly, the approach is appropriate for the research. Some of the limitations that have been pointed out in this regard are that because of their different origin data cannot be compared and is very expensive in terms of research 
effort (Flick et al., 2004; Bryman and Bell 2011; Fusch et al., 2018). The methodological design based on analytical and casuistic triangulation implemented allows us to obtain a comprehensive view of digital marketing practices and their results in the context of the environment that surrounds them and contributes to the validity of the information gathering instruments as well as their processing and interpretation. Although these are techniques well known, the mixing of them is not frequent in the field of business management studies (digital marketing). The stages and activities of the methodological process will describe in detail below.

\section{Performance Assessment}

i) Case study selection

The decision to choose companies in the tertiary sector as case studies were due to their high occupational representativeness since that sector employs $70 \%$ of the municipal workforce according to our estimates from the last economic census (2019). Considering the casuistic triangulation approach and the research objectives, was determined to select three companies that meet the following characteristics: i) Have a branch office, clients, perform services, trade, and marketing activities in the RB-LRGV cross-border region; ii) Be market leaders in their industry; iii) Have more than fifteen years of operation. The database to filter the case studies was made considering the list of members of the association of businessmen of the commercial and service sector of the City of Río Bravo Tamaulipas. Initially, a list of five companies identified, however, after visited them to request their cooperation for the research, we had affirmative answers in three of them.

ii) Design and application of information gathering instruments

The instruments for gathering information ${ }^{10}$ were formulated based on the proposals of previous studies and validated and enriched through focus groups of a panel of experts made up of three businesspeople, three managers from the region, and three academics specialists in marketing (Figure 2).

Figure 2. Sources for the development of the instruments

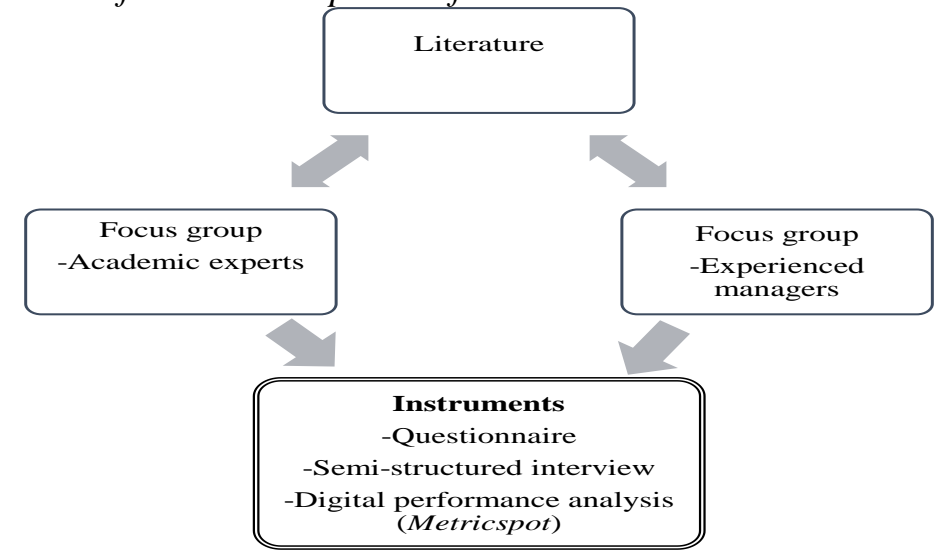

Source: Authors' elaboration.

\footnotetext{
${ }^{10}$ See questionnaire in Appendix 1 and interview script in Appendix 3.
} 
The use of the focus group technique linked to triangulation not only makes the data more complete but also allows a better understanding of the phenomenon being studied (Figure 2). Thus, focus groups can make a valuable contribution when used in mixed-method studies, not only in terms of the data generated but also in terms of perceptions (Caillaud and Flick, 2017).

We made the panel of experts considering their experience, domain of the topic, and knowledge of the regional cross-border environment of the case studies. Once they agreed to participate in the project, two meetings were set up with each of the panels. The first was held in the second week of January 2019 took 30 minutes to explain the research objectives and the expected contribution of the participants. The second stage of meetings with the same members and was held between the end of January and the beginning of March 2019, for around 95 minutes each. A draft version of the instruments was integrated and sent by e-mail to the experts for review and final suggestions.

Based on comments, the new version was updated, and the pilot test performed with two companies related to the companies studied (Figures 2 and 3), then the final version of these tools was obtained (Appendices 1 and 3).

Figure 3. Development process of instruments for collecting and analyzing information

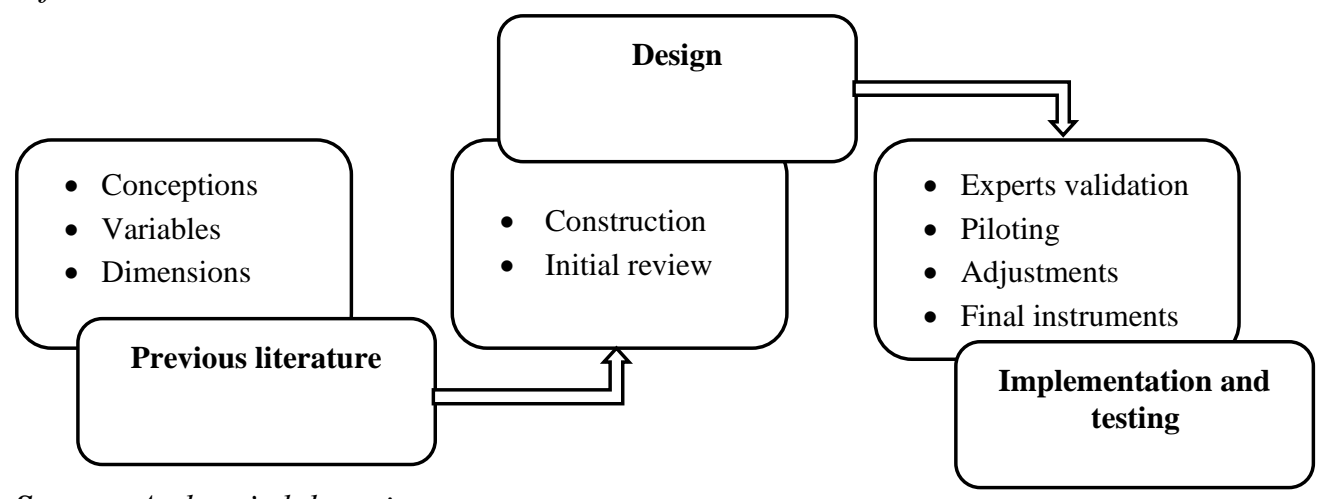

Source: Authors' elaboration.

In the questionnaire, different Likert scales were used to provide a precise analysis, but open-ended questions were also included in which the participants argued about affirmative and negative answers (see Appendix 1). The questionnaires were applied to company's marketing decision-makers. The analysis was purely quantitativedescriptive, and from the results, the validated version of the semi-structured interview script was feedback. The interview was then conducted with the same respondents and analyzed in an interpretative way through an a priori categorical analysis, based on the dimensions that formed both instruments. 
Figure 4. Categorical dimensions analyzed

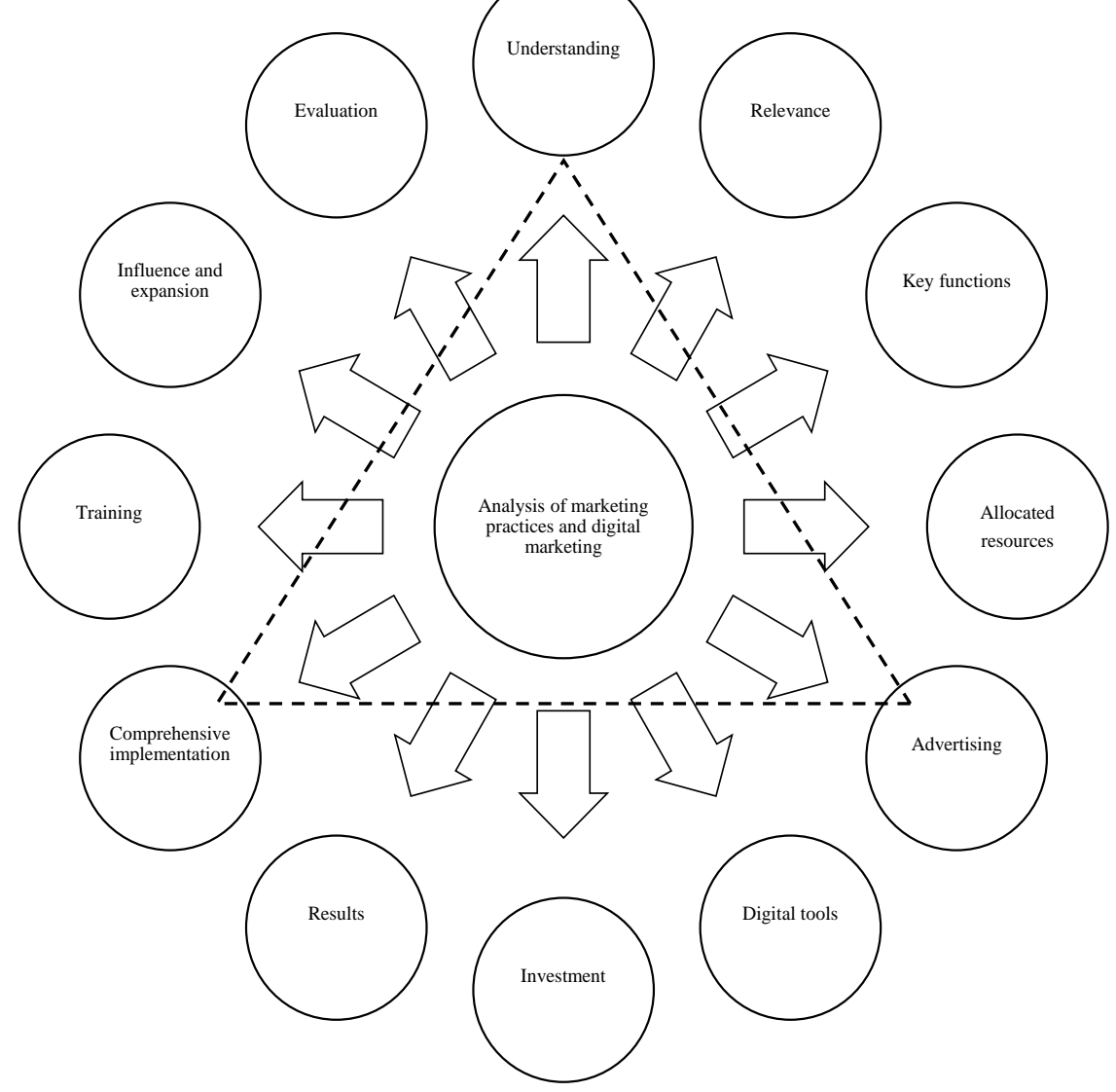

Source: Authors' elaboration.

Both the questionnaire and the semi-structured in-depth interview allowed us to understand the practices, as well as the perception of marketing efforts within the companies. However, by the nature of these techniques, subjectivity is implicit in its implementation.

iii) Parametric assessment of digital marketing performance

To enhance the results of digital performance is necessary to make appropriate measurements. For this purpose, Järvinen and Karjaluoto (2015) and Saura et al. (2017) propose the suitability implementing different web analysis options. Therefore, to complement and objectively contrast the digital marketing practices performance (web page and Facebook), we implemented a tool named Metricspot ${ }^{11}$. It is an online free software that allows the analysis of more than fifty SEO (Search Engine Optimization) parameters of a web page to detect the weaknesses that may

${ }^{11}$ Taking as a methodological reference the paper by López et al. (2017). The tool can be consulted at https://metricspot.com 
be present on it. In the beginning, summary results are shown with a score on each aspect that disagrees in the report, SEO authority, basic SEO, content, usability, technical details, and social networks (Appendix 3). Also, it generates an overall score and provides detailed information on each parameter analyzed and provides relevant information on the performance of the websites and Facebook of the analyzed companies.

\section{Results and Recommendations}

\section{i) Questionnaires}

Based on the responses provided by each company, a summary table was drawn up for comparative purposes (Appendix 2). Regarding the interpretation of the marketing concept, they offered fragmented notions. One reduces it to sales, another to positioning, and the third one to advertising. Concerning digital marketing, they conceive it as the use of the Internet for advertising purposes. The previous conceptions contrast with the relevance they give to marketing since the three companies consider it as "very important" and "important".

In terms of functions, it is more evident that marketing efforts are focused on a few areas. Among these, advertising stands out, since all three refer to it. Furthermore, company "A" answered to perform "Product development and pricing" while "B" and "C" referred to it as a function of distribution and logistics channels. When considering the distribution of resources, the main role of advertising is more significant due it concentrates on average more than 70\%. Concerning advertising, we confirmed that the companies use it frequently, but the company " $\mathrm{A}$ " is the one that performs a greater variety of activities. In digital marketing tools, there is a consensus referring basically to social networks and the Internet, but especially Facebook as the most important.

In terms of investment amounts there are differences. The " $\mathrm{A}$ " has the highest amounts within the monthly basis of $\$ 1,000$ to $\$ 1,500$, followed by "B" $\$ 500$ to $\$ 999$ and finally the " $\mathrm{C}$ " between $\$ 200$ and \$499, however, the "C" also mentioned that it is an outlay that can be variable depending on the agricultural season. They agree that the investment has generated the expected results and identify as main benefits to obtaining more clients, market, sales, and even that it has contributed to the identity of the personnel.

Regarding the degree of knowledge, those responsible for marketing reveal levels that hover around a low intermediate level, that is, they recognize large areas of opportunity. This goes hand in hand with expressing that they do not implement a comprehensive marketing approach. Although they refer to knowing different types of digital marketing, we can notice that they do not know those of "new generation" which offer more analytical potential, among them: SEO, search engines, contents, and affiliate marketing networks. According to this, all of them express the need to be trained to implement digital marketing tools. 
All mention that digital marketing contributes to the international growth of the company. Among the reasons, they mention an increase in potential customers in the cross-border region. The three companies know the importance of the international arena to grow and get new clients. They also agree on the significant contribution of investment to growth through advertising, positioning, and information. They also highlight the role played by the border environment in which the companies are located. It is noteworthy that none of the companies evaluate the impact of marketing and are unaware of the tools to assess the performance of digital marketing.

\section{ii) Interviews}

Textual transcripts of the interviews are presented in Appendices 5 and 6. The main result are presented in this section. In company "A" when they start to use social networks as a marketing tool, the informant mention to use Facebook since 2015, however, they did not expect to have a significant impact as television advertising. She referred not using another social network and added: "Facebook is the most important". The reasons for using it are "... low cost, easy to use, and the impact it has".

Considering that social networks have several years registering high levels of diffusion and number of users, their role in social and commercial life has become notably relevant. Although in the case referred to, is very recent the use of these platforms, it has brought very positive results, which allowed to position, maintain and grow in the market since it is a company with 25 years of operation, the experience and its history is something that gives it a competitive advantage.

Regarding the time of use who else uses it (besides the owner) and who provides maintenance; the informant told us that she relies on her workers for publications on Facebook and the use she makes of it is not daily, it is once a week or twice a month: "...so as not to bore people". She also mentions investing in commercial spaces within the same network, so that posts had more reach, as she considers that this way people will be more interested in reading them.

Managing a company entails great responsibility since its functionality depends on many factors, whatever the field. Undoubtedly, she should have exclusive personnel for this area, as from the interview and the visit on-site, it was evident not to be in a condition to provide strategic follow-up to the marketing or to operate the social networks as someone specialized. Time is also an important factor that influences performance, and not having a person in charge exposes them to make mistakes in the management of social networks.

Other questions were how the tool had an impact on marketing. She explained that despite having a website and other digital resources: "...there is nothing like Facebook" ... "this social network has low cost and people are more interested in". About the impact, she added: "is a lot" and considered "for all the businesses it was 
a great change". Regarding the need for training or specialized personnel to manage social networks, she stated: "Is necessary, although for the moment it would be more feasible to receive training for taking advantage of the possibilities offered by this social network since it is more than just posting ads, images and answering messages".

On the other hand, the interview with the head of the marketing area in company " $B$ " yielded interesting information that allows us to contrast with the previous company. When asked if he used another social network in addition to Facebook, he mentioned: "We use Twitter and we also have a web page". Considering that it is a company dedicated to providing a transportation service, they need to have a website that provides information about the services they offer, the experience the company has, all of this to demonstrate reliability to future customers. He also pointed out that Facebook is the most important social network and that the main reason for using it is because it is: "...a means of community communication that allows you to send a clear message to a specific niche for low or no cost". Bearing in mind that the Facebook social network options allow you to select the niches you want to find it is helpful to reach more potential customers interested in the company.

The year the company started to implement social networks, was from 2016 onwards. The way they handle digital platforms has brought them considerable results, perhaps not in terms of attracting direct customers, but in image, prestige, and being at the forefront. Other relevant questions were, what advantages or disadvantages had using Facebook? and if he considers this tool had an impact on marketing? He answered the main advantages are "...low cost and that the message is direct, there is also contact with customers and it provides you with a market analysis". Concerning the impact, he said: "yes, it is very important, and it is a main process of marketing".

Even though company "B" is freight services and its main clients are not users of social networks, it is noteworthy the importance assigned to implementing strategies ad hoc. They refer that: "...like all companies, digital marketing, handling it in the right way, with sales strategies, giving a correct use to the options it offers, will always be an advantage". The manager also states: "Is urgent to train us to make more professional the use of social networks and thus have an impact and close the gap we currently have on that issue".

On the other hand, company "C" was not asked the same questions as in the interview, due they said that since 2017, they no longer use social networks and only did so for about a year. The reason for this decision, the manager said that "...the company's business is different and we do not think it is appropriate to implement social networks as a marketing strategy since most of our clients are older people who work in the countryside". Additionally, he declared his preference for investing in the tools used by sales agents and in the good service they provide to their clients. 
iii) Parametric analysis of digital marketing performance

It is often thought, because of the company's business sector, it would not be relevant to implement social networks or a digital marketing strategy. However, as time goes by and the social media web advances, many companies realize the importance of being present and creating communities through better content. Using Metricspot, we made a comparison on web quality between Facebook pages and the websites of companies "A" and "B", based on the indicators shown in Appendix 4.

Table 2. Web quality comparison of Facebook pages*

\begin{tabular}{|l|l|l|}
\hline Dimension & Company “A” & Company “B” \\
\hline SEO authority & $100 \%$ & $100 \%$ \\
\hline Basic SEO & $88.0 \%$ & $88.0 \%$ \\
\hline Content & $62.5 \%$ & $62.5 \%$ \\
\hline Usability & $80.5 \%$ & $80.5 \%$ \\
\hline Technical aspects & $55.0 \%$ & $66.0 \%$ \\
\hline Social networks & $92.2 \%$ & $92.2 \%$ \\
\hline Average & $\mathbf{7 9 . 7 \%}$ & $\mathbf{8 1 . 5 3} \%$ \\
\hline
\end{tabular}

Note: *Company " $C$ " is not included since it does not use this resource.

Source: Authors' elaboration based on Metricspot.

The average registered in Table 2 shows that " $B$ " performance is slightly higher than "A", however, it does not necessarily mean that it is a good result. The results are almost the same, except for the "technical aspects" category, in which the first company is higher than the second. This difference is $11 \%$, which indicates that in the different variables analyzed, performance can be better when a programming professional is present. Both companies should focus on this indicator since the lowest score was obtained in that item. A possible solution, as mentioned, is to train their staff or hire someone specialized in marketing or digital marketing.

Company "A" only has Facebook as a social network, therefore, only the web quality of "B" and "C" will be analyzed with the same indicators mentioned above.

Table 3. Website quality analysis

\begin{tabular}{|l|l|l|}
\hline Dimension & Company "B" & Company "C" \\
\hline SEO authority & $5.6 \%$ & $0.10 \%$ \\
\hline Basic SEO & $57 \%$ & $35.3 \%$ \\
\hline
\end{tabular}




\begin{tabular}{|l|l|l|}
\hline Content & $46.4 \%$ & $21.4 \%$ \\
\hline Usability & $32.9 \%$ & $33.2 \%$ \\
\hline Technical aspects & $39 \%$ & $44.5 \%$ \\
\hline Social networks & $0 \%$ & $6.3 \%$ \\
\hline Average & $\mathbf{3 0 . 1 5} \%$ & $\mathbf{1 8 . 5} \%$ \\
\hline
\end{tabular}

Note: *Company "A" is not included since it does not use this resource.

Source: Authors' elaboration based on Metricspot.

The results in Table 3 reveal a low average due to low indicators in SEO authority, which means that there are technical elements in the web itself that affect its positioning, such as titles, URL and keywords used. Another low performance is social networks because the website is not linked, however, customers do not only search the website, they also use social networks to get information. Although companies have a website and company "B" even has staff in the marketing department, they omit certain specifications that affect web quality performance. In summary, there is a large area of opportunity to improve digital performance.

\section{iv) Recommendations}

According to the results, we recommend specific actions to each company. For company " $\mathrm{A}$ " is necessary to expand the criteria they have regarding marketing to improve and take advantage of the use of different channels, such as a website. Formulate a strategy to introduce social networks, mainly Facebook and Instagram, schedule weekly basis content, and create templates for photo content including logo, watermarks and contact information such as telephone, service hours, and the name of staff providing services. They take advantage of social networks because the potential client is segmented and it is easy to reach, for example in holidays and seasons that set trends in styling.

For company "B" some of the recommendations we propose are documented marketing processes; follow up on new strategies and trends in digital marketing. Is important to mention that this company has revolutionized its digital marketing practices in the last six months, compared to the first analyses made at the beginning (in 2017) with the recent ones (August 2019), is more frequent in terms of content programming, more professional in design and terms of the variety of activities, concept, and marketing objectives.

For company " $\mathrm{C}$ " we recommend to reconsider how to implement and incorporate into social networks; create templates for photo content containing logo, watermarks and contact information such as phone number, service hours, name of staff providing services and website; planning a calendar for programming weekly content, and updating information on the website. Having a website is important for 
any company because it is a space with unique content. Nevertheless, it is crucial to give it the importance it deserves, since not doing so can affect the corporate image, and there are still people who are not Facebook users. In this sense, we highlight the point of not having someone specialized in marketing, which can be a disadvantage since they would be limited to only a few ideas that for the moment work. Also, one should not forget that there are always new trends, especially on the web, which is unpredictable and dynamic.

Finally, another general recommendation goes to the direction of the need to reinvent their concepts and, most importantly, marketing practices, since they are limited and fail to take advantage of many opportunities. For instance, designing better-segmented strategies, exploiting web analytics data, analyzing the impact of marketing actions, building more professional content, as well as connecting with old and potential customers.

\section{Conclusions and Implications}

While this paper's methodological and case-based approach is different from traditional studies, our findings agree that investing and implementing digital marketing tools benefits business expansion and market growth. We also concur that training in the use of digital platforms and continuous performance measurement using web analytics tools is necessary to optimize results.

With no intention of generalizing and considering the positive results that companies have had despite the poorly strategic implementation of digital marketing, we propose that for cross-border companies on both sides of the U.S.-Mexico border, it would be of high management value to engage in that direction. The geographic location of the companies in this border region offers great potential for the expansion of their business projects due to strong political, economic, and social ties. This approach could be applied to other border areas with similar characteristics.

Contrasting marketing efforts, we found that companies agree on aspects such as the leadership they offer in their products and services, even though they are different in terms of marketing practices. For example, company "A" implements many actions, most of them in traditional advertising channels. Company "B" focuses on social networks and a web page, company " $\mathrm{C}$ " manages a low profile in marketing-related activities. In general, companies perform a limited idea regarding digital marketing. Overall, we note in the three companies analyzed, marketing is conceived as an isolated activity, as relies on advertising activity, which restricts its potential benefits in consolidating into international markets. The conceptions go in the direction that it is a process that can be in an improvised way. These results support the research hypothesis.

Even though there are points that apply more particularly to certain organizations, there are others that could apply to all. For example, it is always important to 
interpret the client's requirements and define a strategy according to the firm's industry, maturity, positioning, size, and resources, so in terms of digital marketing, is essential to select and implement a creative proposal and then create content that generates results.

In summary, the article contributes to the research agenda of digital marketing, however, there are still many paths to follow in regional studies, whether subnational, cross-border or transnational since these spaces can offer interesting perspectives and results in the field. In the future, we suggest exploring the possibility of having a database that allows for the increase of sample size and the use of quantitative analysis techniques at the company and regional level to contrast the results. In this regard, we call on the organizations leading the joint study Future of Business Survey to ensure that in future editions, the database they develop offers greater disaggregation, obviously without risking the privacy of participating companies in the sampling.

\section{References:}

Al Alwan, A., Rana, N.P., Dwivedi, Y.K., Algharabat, R. 2017. Social Media in Marketing: A review and analysis of the existing literature. Telematics and Informatics, 34(7), 1177-1190. DOI: 10.1016/j.tele.2017.05.008.

Al Ganideh, S.F., Hamam, M.Z. 2019. Is It a New "Facebook Revolution" in the Arab World? Exploring Young Jordanians' E-Purchasing Behavior. Competition Forum, $17(2)$.

Ainin, S., Parveen, F., Moghavvemi, S., Jaafar, N.I., Mohd Shuib, N.L. 2015. Factors influencing the use of social media by SMEs and its performance outcomes. Industrial Management \& Data Systems, 115(3), 570-588. DOI: 10.1108/IMDS-07-2014-0205.

Ayswarya, R., Telreja, S., Praveena, S., Mathiazhagan, I. 2019. Facebook: A Boon or Bane towards Social Media Marketing. Journal of Service Science and Management, 12(5), 628-638. DOI: 10.4236/jssm.2019.125043.

Banks, A., Haan, P. 2017. Facebook and Branding of Small to Medium-Sized Enterprises. Association of Marketing Theory and Practice Proceedings, 2017(9). https://digitalcommons.georgiasouthern.edu/amtp-proceedings_2017/9.

AMIPCI. 2019. $15^{\circ}$ Estudio sobre los Hábitos de los Usuarios de Internet en México 2018. https://www.asociaciondeinternet.mx/estudios/habitos-de-internet.

Bryman, A., Bell, E. 2011. Business Research Methods. Oxford University Press, $3^{\text {rd }}$ edition. Oxford.

Caillaud, S., Flick, U. 2017. Focus Groups in Triangulation Contexts. In Barbour, R., Morgan, D. (Eds). A New Era in Focus Group Research. Palgrave Macmillan, London.

Cañueto, J. 2016. Estrategias de marketing digital y en redes sociales que aplican las agencias de viaje del centro de Mar del Plata. Facultad de Ciencias Económicas y Sociales. Universidad Nacional de Mar del Plata, Argentina.

Chaffery, D., Ellis-Chadwick, F. 2019. Digital marketing, strategy, implementation and practice. Pearson, $7^{\text {th }}$ edition, England.

Chang, H., Chou, Y., Wu, D., Wu, S. 2017. Will firm's marketing efforts on owned social media payoff? A quasi-experimental analysis of tourism products. Decision Support Systems, 107, 13-25. DOI: 10.1016/j.dss.2017.12.011. 
Chmielecki, M. 2014. The use of Facebook for marketing purposes among SMES as a modern marketing method research results from Poland. Journal of Lviv Polytechnic National University, Series of Economics and Management Issues, 207-217. Akademy of Managment in Lodz, Poland.

Clark, T. 1994. National Boundaries, Border Zones, and Marketing Strategy: A Conceptual Framework and Theoretical Model of Secondary Boundary Effects. Journal of Marketing, 58(3), 67-80. DOI:10.2307/1252311.

CONAPO. 2018. Proyecciones de la población de México, de las entidades federativas, de los municipios y de las localidades 2016-2050, CONAPO, México.

Daniels, J.D., Radebaugh, L.H., Sullivan, D.P. 2018. Negocios internacionales: ambientes y operaciones. Pearson, $16^{\text {th }}$ edition, Ciudad de México.

Dzisi, S., Ofosu, D. 2014. Marketing strategies and the performance of SMEs in Ghana. European Journal of Business and Management, 6, 102-109.

Epetimehin, F.M. 2013. Cross-border insurance marketing and the corporate implications. European Scientific Journal, 9(1),152-162.

Flick, U., von Kardorff, E., Steinke, I. 2004. What is qualitative research? In U. Flick, E. von Kardorff, I. Steinke (Eds.). A Companion to Qualitative Research, SAGE Publications Ltd., London.

Flick, U. 2018. Qualitative Research kit: Doing triangulation and mixed methods. SAGE Publications Ltd., London.

Fusch, P., Fusch, G.E., Ness, L.R. 2018. Denzin's Paradigm Shift. Revisiting Triangulation in Qualitative Research. Journal of Social Change, 10(1), 19-32.

Galati, A., Crescimanno, M., Tinervia, S., Fagnani, F. 2017. Social media as a strategic marketing tool in the Sicilian wine industry: evidence from Facebook. Wine Economics and Policy, 6(1), 40-47.

Gálvez, P., Martín, C. 2009. Redes sociales como fuente de capital social: una reflexión sobre la utilidad de los vínculos débiles. RISTI -Revista Ibérica de Sistemas e Tecnologias de Informação, (3), 13-24.

Gutiérrez-Leefmans, C., Rogel, R.M.N., Trujillo-León, M.A. 2016. Marketing Digital num País Emergente: estudo Exploratório do Marketing Mix de PME com Selo de Confiança. Revista Brasileira de Marketing, 15(2), 207-219.

INEGI. 2009. Censos Económicos 2009. INEGI, México.

INEGI. 2014. Censos Económicos 2014. INEGI, México.

INEGI. 2019. Censos Económicos 2019. INEGI, México.

INEGI. 2015. Encuesta Intercensal de Población y Vivienda 2015. INEGI, México.

Järvinen, J., Karjaluoto, H. 2015. The use of Web analytics for digital marketing performance measurement. Industrial Marketing Management, 50, 117-127.

Kannan, P.K., Li, A. 2017. Digital marketing: A framework, review and research agenda. International Journal of Research in Marketing, 34(1), 22-45. DOI: 10.1016/j.ijresmar.2016.11.006.

Liang, T., Turban, E. 2011. Introduction to the special issue social commerce: a research framework for social commerce. International Journal of Electronic Commerce, 16(2), 5-14.

López, M.J., Continente, X., Sánchez, E., Bartroli, M. 2017. Intervenciones que incluyen webs y redes sociales: herramientas e indicadores para su evaluación. Gaceta Sanitaria, 31(4), 346-348. DOI: 10.1016/j.gaceta.2016.12.006.

Martínez, J. 2017. Estudio de Caso Sobre la Relación Entre Redes Sociales y Escuela en los Procesos de Aprendizaje. Universidad Escuela y Sociedad, (3), 46-62. 
Nijssen, E., Van Herk, H. 2009. Conjoining International Marketing and Relationship Marketing: Exploring Consumers' Cross-Border Service Relationships. Journal of International Marketing, 17(1), 91-115. Retrieved from: www.jstor.org/stable/27755590.

McDaniel, C., Parks, D. 2019. Businesses on Facebook and Propensity to Export: Australia. Policy Brief, Mercatus Center of George Mason University.

Oliveras, X. 2015. Estrategias de marketing territorial en una región transfronteriza: Tamaulipas-Texas. Si Somos Americanos, Revista de Estudios Transfronterizos, 15(2), 97-122.

Saura, J.R., Palos-Sánchez, P., Cerdá, L.M. 2017. Understanding the Digital Marketing Environment with KPIs and Web Analytics. Future Internet, 9(4), 76.

Statista. 2020. Most popular social networks worlwide as of January 2020. Statista. Retrieved from: https://www.statista.com/statistics/272014/global-social-networks-ranked-bynumber-of-users/.

Teemu, M. 2016. Cross-border shopping and tourism destination marketing: the case of Southern Jutland, Denmark. Scandinavian Journal of Hospitality and Tourism, 16(1), 36-50.

Texas Department of Transportation. 2019. Texas-Mexico International Bridges and Border Crossings. Freight, International Trade, and Connectivity, Transportation Planning and Programming Division.

Tiago, M.T.P.M.B., Veríssimo, J.M.C. 2014. Digital Marketing and Social Media: Why Bother? Business Horizons, 57(6), 703-708.

Vargas, J.G. 2005. Mercadotecnia transfronteriza de servicios de salud en Tijuana. Revista Escuela de Administración de Negocios, (53), 94-125. Retrieved from https://www.redalyc.org/articulo.oa?id=206/2060 5308.

Yin, R.K. 1994. Case Study Research Design and Methods: Applied Social Research and Methods Series. SAGE Publications Inc., $2^{\text {nd }}$ edition, Thousand Oaks, California.

\section{Appendices:}

Appendix 1. Marketing practice questionnaire (synthetic version)

Instructions: Answer briefly or select the answer option, as appropriate.

1. In your organization what do you understand by marketing and digital marketing?

\section{What relevance do you give to marketing?}

a) Very important. b) Important. c) Neutral. d) Not important. e) Nothing important.

3. Of the following marketing functions, which one(s) do you implement?

a) Market research. b) Product development and pricing. c) Distribution and logistics channels. d) Advertising. e)Other(s)

4. Considering the previous functions, how do you distribute the resources (Financial, Human, Physical and Time) invested?
a)
(\%) b)
(\%) c)
(\%) d)
(\%) e)

5. About advertising, which of the following do you apply, and which is most relevant?
a) Online advertising.
b) Printed advertising.
c) Television and radio advertising.
d) Static advertising.
e) Other

6. What digital marketing tools do you know, and which is most relevant to your business?

7. How much does your company invest in marketing monthly (dollar amounts)?
$\begin{array}{lll}\text { a) Less than } \$ 200 & \text { b) } \$ 200-\$ 499 & \text { c) } \$ 500-\$ 999\end{array}$
d) $\$ 1000-\$ 1,499$
d) $\$ 1,500$ or more

8. Do you think that the investment has given the expected results? (Yes / No) 
9. Mention the three main benefits (If any):

10. On a scale of 1 to 10, how would you rate the level of marketing knowledge and implementation in your company?

11. Does your company have a comprehensive marketing strategy?
a) Strongly agree
b) Agree
c) Neutral
d) Disagree
e) Strongly disagree

12. Which of the following type(s) of digital marketing do you know?

a) Social media b) Content c) Search engine optimization d) Search engines e) Pay per click advertising f) Affiliates

g) Email h) Radio advertising i) TV advertising j) Mobile phone advertising

13. How important do you consider training to implement digital marketing tools?

a) Very important b) Important c) Neutral d) Not important e) Not important at all

14. Do you consider that investment in digital marketing contributes to the international growth of your company? (Yes / No and why?)

15. Do you consider marketing important for the international arena? (Yes / No and Why?)

16. Do you evaluate the impact of your marketing activities? (Yes / No)

17. Do you know tools to evaluate digital marketing?
a) Strongly agree
b) Agree
c) Neutral
d) Disagree
e) Strongly disagree

Thank you very much for your cooperation!

Appendix 2. Questionnaire answers summary

\begin{tabular}{|c|c|c|c|}
\hline Items & Company "A" & Company "B" & Company "C" \\
\hline $\begin{array}{l}\text { 1) Marketing / } \\
\text { Digital } \\
\text { Marketing }\end{array}$ & $\begin{array}{l}\text { "Factor that produces } \\
\text { sales with variable } \\
\text { quality" } \\
\text { "All internet advertising" }\end{array}$ & $\begin{array}{l}\text { "Positioning process } \\
\text { of our brand in the } \\
\text { national and } \\
\text { international market" } \\
\text { "The activities we } \\
\text { carry out using } \\
\text { internet-based } \\
\text { applications" }\end{array}$ & $\begin{array}{l}\text { "Development that helps to } \\
\text { publicize the services } \\
\text { provided by the } \\
\text { agricultural branch" } \\
\text { "The use of different web } \\
\text { resources to publish } \\
\text { advertisements and } \\
\text { information" }\end{array}$ \\
\hline 2) Relevance & "Very important" & "Very Important" & "Important" \\
\hline 3) Functions* & b) and d) & c) and d) & c) and d) \\
\hline $\begin{array}{l}\text { 4) Allocation of } \\
\text { Resources* }\end{array}$ & b) $10 \%$ d) $90 \%$ & c) $25 \%$ d) $75 \%$ & c) $50 \%$ d) $50 \%$ \\
\hline 5) Advertising* & $\begin{array}{l}\text { a); b); c); d); e) } \\
\text { Corporate image }\end{array}$ & $\begin{array}{c}\text { a); c); d); e) } \\
\text { Company's vehicles }\end{array}$ & $\begin{array}{l}\text { a); d); e) Company's } \\
\text { vehicles }\end{array}$ \\
\hline $\begin{array}{l}\text { 6) Digital } \\
\text { Marketing } \\
\text { Tools / Most } \\
\text { Important } \\
\end{array}$ & $\begin{array}{l}\text { "Social networks and web } \\
\text { pages" / "Facebook page" }\end{array}$ & $\begin{array}{l}\text { "Internet, social } \\
\text { media, online } \\
\text { advertising plans" / } \\
\text { "Facebook" }\end{array}$ & $\begin{array}{l}\text { "Internet and web pages"/ } \\
\text { "Social networks } \\
\text { especially Facebook" }\end{array}$ \\
\hline 7) Investment* & c) & b) & a) \\
\hline 8) Results & Yes & Yes & Yes \\
\hline 9) Benefits & $\begin{array}{l}\text { "They have been } \\
\text { favorable as we get more } \\
\text { clients" }\end{array}$ & $\begin{array}{l}\text { "We have more } \\
\text { market and we have } \\
\text { also managed to form } \\
\text { an identity for the } \\
\text { staff" }\end{array}$ & $\begin{array}{l}\text { "The growth in the volume } \\
\text { of sales of seeds and } \\
\text { agrochemicals as well as } \\
\text { the tons of grain received" }\end{array}$ \\
\hline
\end{tabular}




\begin{tabular}{|c|c|c|c|}
\hline $\begin{array}{l}\text { 10) Degree of } \\
\text { knowledge }\end{array}$ & 5 & 6 & 5 \\
\hline $\begin{array}{l}\text { 11) } \\
\text { Comprehensive } \\
\text { approach* }\end{array}$ & d) & d) & e) \\
\hline $\begin{array}{l}\text { 12) Types of Digital } \\
\text { Marketing* }\end{array}$ & a); g); h); i); j) & a); e); g); h); i); j) & a); g); h); i); j) \\
\hline 13) Training* & a) & a) & a) \\
\hline $\begin{array}{l}\text { 14) Impact of } \\
\text { investment on } \\
\text { growth }\end{array}$ & $\begin{array}{l}\text { "Yes" / "The investment } \\
\text { in the growth we obtained } \\
\text { is very relevant since } \\
\text { television advertising } \\
\text { began on a TV channel in } \\
\text { the Texas Valley, and tele } \\
\text { audience was obtained in } \\
\text { both countries, Mexico } \\
\text { and the United States" }\end{array}$ & $\begin{array}{l}\text { "Yes" / "It is of great } \\
\text { importance, especially } \\
\text { in our geographical } \\
\text { position" }\end{array}$ & $\begin{array}{l}\text { "Yes" / "Through the } \\
\text { information the change in } \\
\text { imports of seed and } \\
\text { agrochemicals is } \\
\text { transcendent" }\end{array}$ \\
\hline $\begin{array}{l}\text { 15) Importance in } \\
\text { the } \\
\text { international } \\
\text { arena } \\
\end{array}$ & $\begin{array}{l}\text { "Yes" / "Because we live } \\
\text { in a very privileged area } \\
\text { as it has a border with a } \\
\text { country with high } \\
\text { economic power" }\end{array}$ & $\begin{array}{l}\text { "Yes" / "since while } \\
\text { our activity is } \\
\text { international it opens } \\
\text { doors to new clients" }\end{array}$ & $\begin{array}{l}\text { "Yes" / "Because we are in } \\
\text { an international border } \\
\text { area" }\end{array}$ \\
\hline $\begin{array}{c}\text { 16) Impact } \\
\text { evaluation }\end{array}$ & No & No & No \\
\hline $\begin{array}{l}\text { 17) Digital } \\
\text { Marketing } \\
\text { Performance* } \\
\end{array}$ & d) & c) & e) \\
\hline
\end{tabular}

Note: *According to options of the corresponding questionnaire item.

Source: Author's elaboration based on the questionnaires.

Appendix 3. Interview script

- What are social networks for you?

- What year did you start using social networks?

- Do you use other social networks besides Facebook?

- Which is the most important social network for you?

- Why do you use this platform?

- Are you the only person who manages the company's Facebook account?

- How often do you use this tool?

- Have you invested in advertising on this platform?

- What are the advantages or disadvantages of using Facebook?

- Do you think this tool has had an impact on your marketing?

- In what way?

- Do you consider it is necessary to train or have specialized personnel in the management of social networks?

Appendix 4. Dimensions and indicators of web analytics and web quality

\begin{tabular}{|l|l|l|}
\hline Dimension & Objective / definition & Parameters analyzed $^{\mathbf{1 2}}$ \\
\hline Web Analytics & To know how web users behave. & $\begin{array}{l}\text { Session, User, Pages / Session, time on page, } \\
\text { average session duration, average download time, } \\
\text { page length, bounce rate, dropout rate, conversion } \\
\text { rate. }\end{array}$ \\
\hline Behavior &
\end{tabular}

\footnotetext{
${ }^{12}$ All parameters are defined in the appendix available at https://metricspot.com
} 


\begin{tabular}{|c|c|c|}
\hline Audience & $\begin{array}{l}\text { To know behaviors according to } \\
\text { certain characteristics of the users of } \\
\text { a website. }\end{array}$ & $\begin{array}{l}\text { Language, location, new visitors vs. recurring, } \\
\text { frequency and recent visits, interaction, browser, } \\
\text { networks, devices channels, referrals, social } \\
\text { referrals. }\end{array}$ \\
\hline Acquisition & $\begin{array}{l}\text { To know behaviors according to the } \\
\text { channels and social networks of web } \\
\text { users. }\end{array}$ & Channels, References, Social References. \\
\hline \multicolumn{3}{|l|}{ Quality of a website } \\
\hline SEO Authority & $\begin{array}{l}\text { Authority of a website according to } \\
\text { external factors that affect its } \\
\text { positioning. }\end{array}$ & $\begin{array}{l}\text { PageRank, Alexa Ranking, Moz, Backlinks, } \\
\text { Domain Authority, Open Directory. }\end{array}$ \\
\hline Basic SEO & $\begin{array}{l}\text { Technical elements of the website } \\
\text { itself that affect the positioning of the } \\
\text { website. }\end{array}$ & $\begin{array}{l}\text { Redirection, www, title and meta description, } \\
\text { meta keywords, robot, txt, } \\
\text { sistemap, clean URLs. }\end{array}$ \\
\hline Content & $\begin{array}{l}\text { amount of content, frequency with } \\
\text { which it is updated, optimization and } \\
\text { structure. }\end{array}$ & $\begin{array}{l}\text { Indexed pages, images, on- page links, } \mathrm{H} \text { tags, } \\
\text { highlighted texts, blog. }\end{array}$ \\
\hline Usability & $\begin{array}{l}\text { Aspects that have to do with ease of } \\
\text { use. }\end{array}$ & $\begin{array}{l}\text { URL and favicon, } 404 \text { error page, CSS for } \\
\text { printing, conversion form, language, download } \\
\text { time, mobile optimization. }\end{array}$ \\
\hline Technical aspects & $\begin{array}{l}\text { Aspects that a programming or } \\
\text { computing professional should deal } \\
\text { with. }\end{array}$ & $\begin{array}{l}\text { secure protocol (HTTPS / SSL), meta tags, text / } \\
\text { code ratio, W3C } \\
\text { validation, email privacy, google analytics, web } \\
\text { optimization, web technologies, server } \\
\text { localization, wordpress optimization. }\end{array}$ \\
\hline Social networks & $\begin{array}{l}\text { Aspects related to social networks } \\
\text { linked to the web. }\end{array}$ & Social influence, Facebook page, twitter account. \\
\hline
\end{tabular}

Source: Taken from López et al. (2017).

Appendix 5. Textual extracts from transcript of interview with company " $A$ ”

$\mathrm{E}=$ Interviewer.

$\mathrm{R}=$ Interviewee.

E- "What do you think about social networks?"

R- "I belong to the generation that has experienced all the changes, because now with social networks, unlike the TV spots, people are more interested and we have seen more change in social networks than when we advertised on TV, normally when people see a spot they use time to do other things by standing up and not continuing to watch TV, instead with social networks people are more focused on what they are seeing and pay more attention, if they are interested then they read all the information that we as a business are posting, so yes we have seen a big difference between TV spots and the posts and ads we make on Facebook.

E- "Cost?"

R- "...it's cheaper and more profitable"

E- "Besides Facebook, what other social network do you run?"

R- "...web page, but there is nothing like Facebook, we have benefited a lot because, as I said, the cost is lower, and people are more interested"

E- "What year did you open the Facebook page?"

R- "Two years ago we started to post more, the truth is I didn't believe in the impact, always used to television but it has worked out very well for us"

E- "Are you the only one who manages the company's social networks and website?" 
R- "No, my workers help me."

E- "How often do you use them?"

R- "Not every day so as not to bore people, what we do is to buy advertising so our ads get to many people as possible, but not so often so that when people see it, they become more interested in it because they would not be annoyed by seeing it so often, for example, once a week or every two weeks..."

E- "Advantages or disadvantages of using Facebook?"

R- "It's cheaper than television, and people are more interested..."

E- "Do you think this tool has had an impact on your marketing?"

R- "Very much so, I imagine that, in all businesses, it's a big change that has taken place"

Appendix 6. Textual extracts from transcript of interview with company " $B$ "

$\mathrm{E}=$ Interviewer.

$\mathrm{R}=$ Interviewee.

E- "What are social networks to you?"

R- "It is a means of community communication that allows a clear message to be sent to a specific niche for little or no cost".

E- "Besides Facebook, do you use any other social network?"

R- "Yes, twitter and a Website..."

E- "What year did you start using them?"

R- "2016"

E- "Are you the only one who handles the company's Facebook page?"

R- "... two people from the community manager"

E- "How often do you use this tool?"

R- " Daily "

E- "Have you invested in advertising?"

R- "Yes, on Facebook"

E- "What are the advantages or disadvantages of using Facebook?"

R- "The advantages are that it is a cheap platform, with direct message, you have contact with the customers, and you can make an analysis of the market, and the disadvantage is that the excess of content forces to post very interesting things".

E- "Do you think this tool has had an impact on your marketing?"

R- "Yes, it's our main marketing process". 